Agriculture 2012, 2, 228-243; doi:10.3390/agriculture2030228

OPEN ACCESS

agriculture

ISSN 2077-0472

www.mdpi.com/journal/agriculture

Review

\title{
Aromatic Plants as a Source of Bioactive Compounds
}

\section{Efterpi Christaki $^{1, *}$, Eleftherios Bonos ${ }^{2}$, Ilias Giannenas ${ }^{1}$ and Panagiota Florou-Paneri ${ }^{1}$}

1 Laboratory of Nutrition, Faculty of Veterinary Medicine, Aristotle University of Thessaloniki, 54124, Thessaloniki, Greece; E-Mails: igiannenas@vet.auth.gr (I.G.); ppaneri@vet.auth.gr (P.F.-P.)

2 Animal Production, Faculty of Technology of Agronomics, Technological Educational Institute of Western Macedonia, 53100, Florina, Greece; E-Mail: eleftherios.bonos@gmail.com

* Author to whom correspondence should be addressed; E-Mail: efchris@vet.auth.gr; Tel.: +30-2310999973; Fax: +30-2310999984.

Received: 19 July 2012; in revised form: 29 August 2012 / Accepted: 10 September 2012 / Published: 20 September 2012

\begin{abstract}
Aromatic plants, also known as herbs and spices, have been used since antiquity as folk medicine and as preservatives in foods. The best known aromatic plants, such as oregano, rosemary, sage, anise, basil, etc., originate from the Mediterranean area. They contain many biologically active compounds, mainly polyphenolics, which have been found to possess antimicrobial, antioxidant, antiparasitic, antiprotozoal, antifungal, and anti-inflammatory properties. Currently, the demand for these plants and their derivatives has increased because they are natural, eco-friendly and generally recognized as safe products. Therefore, aromatic plants and their extracts have the potential to become new generation substances for human and animal nutrition and health. The purpose of this review is to provide an overview of the literature surrounding the in vivo and in vitro use of aromatic plants.
\end{abstract}

Keywords: aromatic plants; bioactive compounds; polyphenolics

\section{Introduction}

The growing interest of consumers in substances of natural origin in addition to the increasing concern surrounding potentially harmful synthetic additives has resulted in the use of aromatic plants, their extracts and essential oils, as functional ingredients in the pharmaceutical, food and feed industries [1]. Such industries are currently looking for efficacious, safe and cost effective substances 
with clearly defined modes of action and proven benefits. Plant derived components have considerable potential to fulfill such demands. Although there is still a lack of knowledge, especially regarding the consistency of in vivo trial results and mechanisms of action of various components within the aromatic plants [2], they could be applied as new generation compounds for human and animal health and nutrition. It is also important to take into consideration that improved animal health can translate to improved food safety and quality, which benefits the consumer.

\section{Aromatic Plants}

Aromatic plants, also known as herbs and spices, have been used in the Middle East since approximately $5000 \mathrm{BC}$ for their preservative and medicinal properties, in addition to enhancing the aroma and flavor of foods [3-5]. Their use continues undiminished today and according to the World Health Organization (WHO) nearly $80 \%$ of the planet's population, especially in developing countries still depends on plant produced medicines for their healthcare [6,7]. Additionally, feed additives derived from plants, also called phytogenics or phytobiotics or botanicals, can be included in animals' diets to improve their productivity and the properties of the resulting feed and animal products [8]. Among these natural additives, aromatic plants, their extracts and their essential oils have been examined due to their advantages over the antibiotics as growth promoters. They are residue free and generally recognized as safe (GRAS) [8-10].

Currently, there is an increasing interest in using herbs and spices in animal nutrition, in order to replace the use of antibiotics and ionophore anticoccidials, especially after the ban of antibiotic feed additives within the European Union countries in 2006 and discussions to restrict their use outside Europe $[11,12]$.

Many herbs and spices can be found worldwide, with many originating from the Mediterranean area, either in the wild or cultivated, such as rosemary, oregano, sage, thymus, peppermint and garlic [13-16]. They contain chemical substances such as polyphenols, quinines, flavonols/flavonoids, alkaloids, polypeptides or their oxygen-substituted derivatives [17-19]. Some of these substances can act synergistically, so their bioactivity is enhanced [20]. Some bioactive compounds show therapeutic value, such as antioxidant and antiseptic activities [4,21]. Thus, they may reduce the risk of cancer or cardiovascular diseases [22,23] and may find application as treatments in curing or managing a wide range of ailments such as respiratory diseases and stomach or inflammatory disorders [16]. Generally, the bioactive components in the aromatic plants possess the ability to protect the body from damage caused by free radicals induced oxidative stress by quenching singlet oxygen and inducing cytochrome or other enzymes [4,24]. Moreover, herbs and spices can inhibit oxidative rancidity and delay the development of off-flavor in some products [25,26]. They also contain antimicrobial compounds which contribute to the retardation of microbial growth on foods and especially snack foods and meat products $[2,4,27]$.

\section{Essential Oils}

Aromatic plants contain odorous, volatile, hydrophobic and highly concentrated compounds called essential oils (or volatile or ethereal oils). These are obtained from various parts of the plant such as flowers, buds, seeds, leaves, twigs, bark, wood, fruits and roots $[9,18]$. The essential oils are complex 
mixtures of secondary metabolites consisting of low-boiling-point phenylpropenes and terpenes [11]. The most important families from the point of essential oils are: Asteraceae or Compositae, Lamiaceae or Labiateae and Apiaceae or Umbelliferae [28].

Detailed compositional analysis of volatile compounds of the oils can be obtained by gas chromatography and mass spectrometry [9]. It was found that there are valuable mixtures of mainly terpenoids like linalool, geraniol, borneol, menthol, thujanol, citronnillol, $\alpha$-terpineol and a variety of low molecular weight aliphatic hydrocarbons like phenols (thymol, carvacrol, eugenol, gaiacol) and aromatic aldehydes (cinnamaldehyde, cuminal and phellandral) [29].

The oils are usually extracted by steam distillation, while currently the use of supercritical carbon dioxide extraction has become increasingly popular [30]. Depending on type and concentration, essential oils exhibit cytotoxic effects on living cells, although non-genotoxic. The cytotoxic activity of essential oils is mostly due to the presence of phenols, aldehydes and alcohols [1]. Such cytotoxic activity is of great interest for applications against some human or animal pathogens and parasites, as well as for the preservation of agricultural and marine products [29]. It has been known for centuries that aromatic plants - mainly their essential oils or components - can act versus a large variety of organisms including bacteria, viruses, fungi, protozoa, parasites and insects [31-35]. Moreover, the essential oils can exhibit hypolipidemic [36], antioxidant [37], digestive stimulant [38], and antitoxigenic [39] activities and can also contribute in odor and ammonia control [10].

There are more than 3000 plants used for their essential oils of which about 300 are used commercially as flavors and fragrances [40]. As shown in Figure 1, the food industry uses the oils in soft drinks, food confectionary, etc., and the cosmetic industry uses them in perfumes, skin and hair care products, aromatotherapy, etc., while the pharmaceutical industry utilizes them for their functional properties [30].

Figure 1. Activities and uses of aromatic plants.

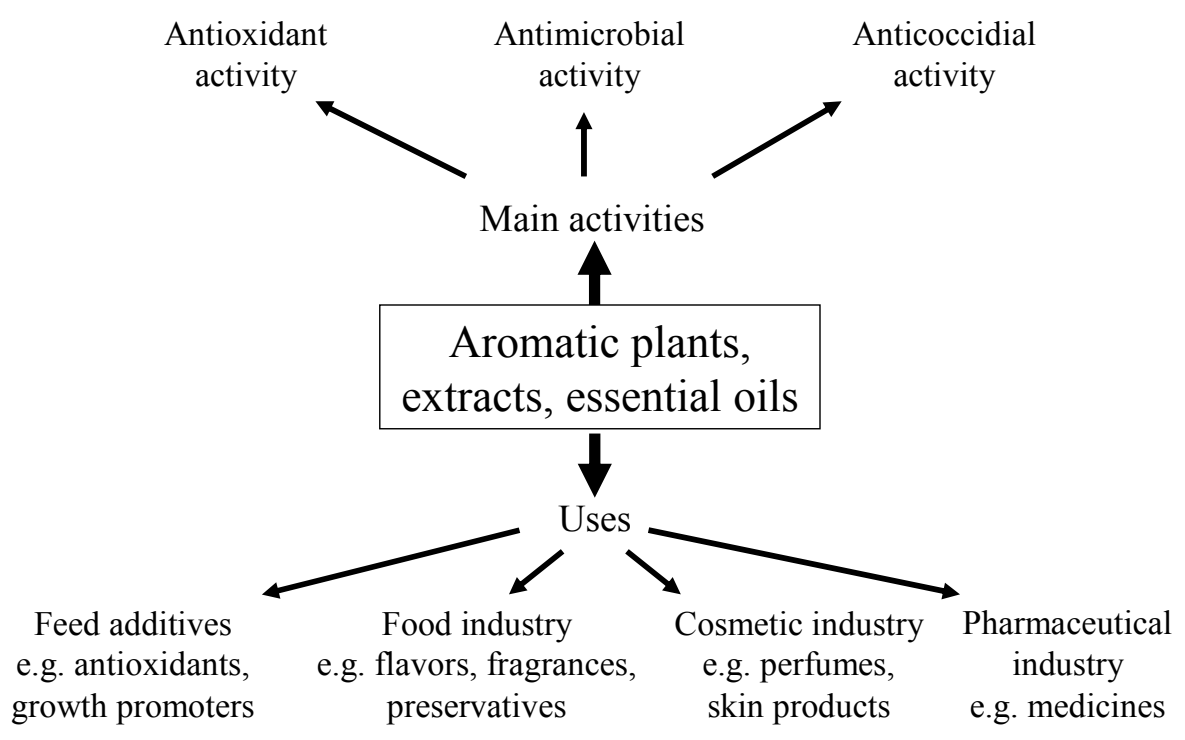




\section{Modes of Action}

\subsection{Antimicrobial Activity}

As already mentioned the antimicrobial properties of the aromatic plants are partially attributed to their essential oils [41,42]. It is suggested that the hydrophobicity of the essential oils and their components is an important characteristic that enables the essential oils to accumulate in the lipid bilayer of the bacterial cell membrane and mitochondria, disturbing the cell structures and rendering them more permeable $[43,44]$.

Moreover, the antimicrobial mechanism of some essential oils is the disruption of cell homeostasis leading to growth inhibition and cell death $[45,46]$. Nevertheless, it has been proposed that the chemical structure, such as the presence of the functional hydroxyl $(-\mathrm{OH})$ group and the aromaticity are also responsible for the antibacterial activity $[2,47,48]$.

The antimicrobial activity of the essential oils has been examined in studies against Gram-negative bacteria, demonstrating high antimicrobial capacity [49,50]. Clinical studies using the essential oils are scarce; they have been tested mainly topically on skin and mucous membranes [51]. Additionally, there is little information as regards safety in relation to the oral administration of essential oils [43]. Currently, essential oils represent a source of natural antimicrobial substances, which may be used in the food industry as biopreservatives to prevent food spoilage and to increase the shelf life of products. Furthermore, the essential oils could reduce side effects caused by the use of chemical preservatives [50].

It is generally accepted that phenolic compounds-having the hydroxyl group attached to a phenyl ring - have the greatest antimicrobial activity among the secondary metabolites found in essential oils [52,53]. Such examples are the monoterpenes carvacrol and thymol and the phenylpropene eugenol [54]. In addition, non-phenolic secondary metabolites found in essential oils have a variable antimicrobial capacity. Some researchers [52] reported that the antimicrobial activity of the monoterpenes $p$-cymene and $\gamma$-terpinene seems to be limited, compared with the phenolic monoterpenes, while others [55] reported that cinnamaldehyde, a non-phenolic phenylpropene exhibits strong antimicrobial activity.

The chemical composition of the essential oils can be influenced by the plant's natural origin, environmental and genetic factors, species and subspecies, geographical location, season of collection, plant part used and method of isolation $[9,56]$.

Some aromatic plants and their extracts have been reported to stimulate the growth of certain bacteria, i.e., to have a prebiotic-type effect [11]. Prebiotics are known for their ability to increase the endogenous intestinal populations of Lactobacillus and Bifidobacterium, resulting in beneficial health effects $[42,57]$. Generally, there are very few in vivo studies of the prebiotic effects of aromatic plants. However, they have been used in ruminants to manipulate rumen metabolism $[11,54]$.

\subsection{Antioxidant Activity}

Aromatic plants and their essential oils are good sources of natural antioxidants, such as phenolic compounds, e.g., eugenol, thymol, carvacrol [58,59]. Polyphenols generally occur as glycosides, although the bioactivity is attributed to aglycon structures and mainly to catechol in aglycons [60]. It is 
considered that the antioxidant activity of these compounds is due to their high redox properties and chemical structure, which can be responsible for neutralizing free radicals, chelating transitional metals and quenching singlet and triplet oxygen by delocalization or decomposing peroxides [61-63]. The above properties are linked to the beneficial health functionality of the phenolic antioxidants because they contribute to the delay of many oxidative-stress related diseases, such as cardiovascular diseases, cancer, diabetes and Alzheimer's [64,65]. Moreover, plant phenols exhibit in vitro antioxidant activity, inhibiting lipid peroxidation by acting as chain-breaking peroxyl-radical scavengers $[66,67]$. Therefore, they can play a protective role for highly unsaturated lipids in feed against oxidative damage [24,67], partly substituting the use of $\alpha$-tocopheryl acetate or preservatives. Lipid oxidation in food products is considered as one of the main factors limiting product quality and acceptability, because of the production of reacting oxygen species (ROS) and off-flavors from polyunsaturated fatty acids $[67,68]$.

Essential oils may also affect lipid metabolism in animal tissues by showing beneficial effects on the antioxidative enzymes (superoxide-dismutase and glutalthione peroxidase) activity, as well as on polyunsaturated fatty acid composition [69]. Consequently, flavonoids are important substances in nutrition, although they are generally considered as non-nutrients [70].

Flavonoids may also act as pro-oxidants, especially those compounds that possess multiple hydroxyl groups [67,71]. After penetrating the inner cells membrane, flavonoids can be oxidized by ROS converting into pro-oxidants, which are able to oxidize lipids, proteins and DNA [19,29]. This mechanism may lead to late apoptosis or necrosis of damaged cells, thus playing a "protective" role by eliminating potential mutants [29].

\section{In vivo Use of Aromatic Plants}

Apart from in vitro experiments examining the biological activities of herbs and spices, many in vivo experiments have examined their beneficial impact as dietary supplements in nutrition. A summary of these results is presented in Table 1.

Table 1. Use of aromatic plants in animal nutrition.

\begin{tabular}{cccc}
\hline Aromatic plant & Addition & Effect & References \\
\hline Chickens broilers & & & \\
\hline Oregano & Essential oil & No effect on performance & {$[72]$} \\
& & Improved performance & {$[73]$} \\
& & Anticoccidial effect & {$[74]$} \\
& & Improved antioxidant capacity of products & {$[72,75,76]$} \\
Oregano & Dried & Improved performance & {$[77]$} \\
& & Anticoccidial effect & {$[78]$} \\
& & Improved antioxidant capacity of products & {$[77]$} \\
Anise & Essential oil & Improved performance & {$[79]$} \\
Anise & Seeds & Improved performance & {$[80]$} \\
Cinnamon & Extracts & Improved performance & {$[81]$} \\
Cinnamon & Essential oil & Improved performance & {$[82]$} \\
Rosemary & Extracts & Improved antioxidant capacity of products & {$[83]$} \\
\hline
\end{tabular}


Table 1. Cont.

\begin{tabular}{|c|c|c|c|}
\hline Aromatic plant & Addition & Effect & References \\
\hline Sage & Extracts & Improved antioxidant capacity of products & {$[83]$} \\
\hline Artemisia аппиа & Dried leaves & Anticoccidial effect & {$[84]$} \\
\hline Sophora flavescens & Extracts & Anticoccidial effect & {$[85]$} \\
\hline Sideritis scardica & Dried & Anticoccidial effect & {$[86]$} \\
\hline Blend & Essential oils & Anticoccidial effect & [87] \\
\hline Blend & Essential oils & Anticoccidial effect & {$[88]$} \\
\hline Blend & Extracts & Anticoccidial effect & [89] \\
\hline \multicolumn{4}{|l|}{ Laying hens } \\
\hline Mixture & Essential oils & Improved performance & {$[90]$} \\
\hline Saffron & Dried & Improved antioxidant capacity of products & [91] \\
\hline Oregano & Dried & Improved antioxidant capacity of products & [91] \\
\hline Rosemary & Dried & Improved antioxidant capacity of products & [91] \\
\hline \multicolumn{4}{|l|}{ Turkeys } \\
\hline Oregano & Essential oil & No effect on performance & [92] \\
\hline Oregano & Dried leaves & Improved feed conversion & [93] \\
\hline Garlic & Dried & Improved performance & {$[94]$} \\
\hline \multicolumn{4}{|l|}{ Laying quail } \\
\hline Oregano & Dried plant & No effect on performance & [95] \\
\hline Anise & Seeds & No effect on performance & [96] \\
\hline \multicolumn{4}{|l|}{ Rabbits } \\
\hline \multirow[t]{4}{*}{ Oregano } & Essential oil & No effect on performance & {$[97,98]$} \\
\hline & & Improved antioxidant capacity of products & {$[97,98]$} \\
\hline & & Improved health and carcass composition & [99] \\
\hline & & Inhibition of microbial growth & {$[98]$} \\
\hline Oregano & Dried & Improved performance & [100] \\
\hline Sage & Extracts & Improved health and carcass composition & [99] \\
\hline \multicolumn{4}{|l|}{ Ruminants } \\
\hline \multirow[t]{2}{*}{ Various plants } & Essential oils & Improved feed utilization & {$[44]$} \\
\hline & & Inhibition of ruminal methanogenesis & {$[44,101,102]$} \\
\hline
\end{tabular}

\subsection{The Use of Aromatic Plants in Poultry Nutrition}

\subsubsection{The Use of Aromatic Plants as Performance Enhancers in Poultry Nutrition}

Dietary oregano oil (50 and $100 \mathrm{mg} / \mathrm{kg}$ of feed) had no effect on performance of chickens [72]. Furthermore, dietary oregano oil (100 and $200 \mathrm{mg} / \mathrm{kg})$ did not improve the performance of turkeys [92]. Nevertheless, dehydrated oregano plants $(5 \mathrm{~g} / \mathrm{kg})$ exerted a growth promoting effect (better body weight gain and feed conversion ratio) when incorporated in chicken diets [77]. Dried oregano leaves $(1.25,2.5$, and $3.75 \mathrm{~g} / \mathrm{kg})$ improved feed conversion ratio in early maturing female turkeys [93]. In addition, the dietary inclusion of dried oregano (10 or $20 \mathrm{~g} / \mathrm{kg} \mathrm{diet}$ ) had no effect on the performance parameters of laying quail [95]. Furthermore, Basset [73] reported that oregano 
essential oil improved the performance of chickens when supplemented through drinking water at 150 or $300 \mathrm{mg} / \mathrm{L}$. These inconsistent results might be attributed to differences in the environmental conditions and/or the composition of the oregano supplement [77]. Due to the fact that the essential oil has much higher content of active substances, it is usually added in much lower percentages in the feed compared to dried plants. The major constituents of oregano are carvacrol, thymol, $\gamma$-terpinene and $p$-cymene, ranging between 802 and $984 \mathrm{mg} / \mathrm{kg}$ of the total plant [103,104].

In addition, anise (Pimpinella anisum) essential oil dietary supplementation at $400 \mathrm{mg} / \mathrm{kg}$ diet in broilers, resulted in significant better body weight gain and feed conversion ratio [79]. Similar results were reported by Soltan et al. [80] when broilers were fed anise seeds at $0.5-0.75 \mathrm{~g} / \mathrm{kg}$ diet. Christaki et al. [96] found that anise seeds (10 or $20 \mathrm{~g} / \mathrm{kg}$ diet) had no effect on the performance of the laying Japanese quail. Anise contains a number of bioactive compounds, anethole (main compound), pseudoisoeugenol, coumarins, scopoletin, umbelliferon, estrols, terpene hydrocarbons, polyenes and polyactylenes [105]. The use of powdered garlic (Allium sativum) as a feed additive $(0.5 \%)$ in broiler chickens improved their performance [94]. The main bioactive compound of garlic is allicin, which exhibits remarkable antimicrobial activity [106]. Furthermore, the dietary addition of cinnamon extracts [81] or cinnamon essential oil [82] improved the performance of broilers compared with control groups. The findings of Bozkurt et al. [90] in laying hens showed that the essential oil mixture of six different plants (oregano, laurel, sage, myrtle, fennel and citrus) is an effective performance enhancer.

Still more work needs to be done in this area, since many other aromatic plants are possible candidates as performance enhancers in poultry nutrition.

\subsubsection{The Use of Aromatic Plants as Anticoccidials in Poultry Nutrition}

Coccidiosis, which is caused by protozoa of the genus Eimeria, is an intestinal parasitosis common in poultry. Coccidiosis is considered as one of the most severe health and welfare problems and is mainly controlled with the use of anticoccidial substances and on a lesser scale with vaccinations $[89,107]$. Certain dietary factors may diminish the negative effects of avian coccidiosis, including the use of herbs and spices [108]. Allen et al. [84] reported that dried leaves of Artemisia annua could protect chickens against caecal lesions caused by Eimeria tenella infection. Youn and Noh [85] found that Sophora flavescens extracts were more effective than Artemisia annua against E. tenella infection in chickens. Evans et al. [87] who investigated an essential oil blend from clove, thyme, peppermint and lemon, found a reduction of coccidia oocyste excretion in chicks fed the diets which contained the essential oil mixture. Aromatic plants of the Labiatae family and especially oregano exhibit coccidiostatic action against E. tenella, when the essential oil or ground leaves, flowers and stems of the plant are incorporated into chicken diets [74,78]. Another aromatic plant of the Mediterranean flora, belonging to the Labiatae family, Olympus tea (Sideritis scardica), exerted a coccidiostatic effect in broiler chickens challenged with $6 \times 10^{4}$ sporulated oocysts of E. tenella, although this effect was considerably lower than that exhibited by the commercially used anticoccidial lasalocid [86].

Analogous results were reported by Christaki et al. [88] in which a blend of herbal extracts from the plants Agrimonia eupatoria, Echinacea angustifolia, Ribes nigrum and Cinchona succirubra 
were fed to chickens experimentally challenged with $6 \times 10^{4}$ sporulated oocysts of E. tenella. Also, Azcrewska-Wlosek and Swiarkiewicz [89] concluded that treatment with a herbal extract mixture containing Allium sativum, Salvia officinalis, Echinacea purpurea, Thymus vulgaris and Origanum vulgare partly alleviates the negative impact of Eimeria experimental infection (E. acervulina, E. tenella, E. maxima and E. necatrix) in broiler chickens.

These studies are important considering the need to find alternative solutions to chemical anticoccidials is of special urgency because European Union countries are planning to ban the use of chemical anticoccidials in livestock nutrition at the end of 2012 [109].

\subsubsection{The Use of Aromatic Plants as Antioxidants in Poultry Nutrition}

Some herbs of the Labiatae family have been extensively studied for their antioxidant activity. It has been shown that dietary supplementation with extracts of rosemary and sage [83] or oregano essential oil could improve the oxidative stability of raw and precooked broiler meat products during refrigerated storage [72,75] or frozen storage at $-20^{\circ} \mathrm{C}$ for a period of up to 9 months [76]. Giannenas et al. [77] reported that the dietary combination of dehydrated oregano and $\alpha$-tocopheryl acetate supplementation in broiler diets exhibited antioxidant activity higher than that presented by $\alpha$-tocopheryl acetate supplementation alone. As regards the effect of aromatic plants on egg yolk, it was reported [91] that saffron, oregano or rosemary had an antioxidative effect on hen egg yolks but this was not as strong as $\alpha$-tocopheryl acetate.

For the above in vivo trials, particularly important is the improved oxidative stability of the poultry meat products or egg yolk, observed may have resulted from the action of antioxidant compounds such as the phenolic isomers thymol and carvacrol found in the extracts and essential oils from the aromatic plants $[58,67]$.

\subsection{The Use of Aromatic Plants in Rabbit Nutrition}

There are a limited number of in vivo trials dealing with the use of aromatic plants in rabbit nutrition. According to Ayala [100] dietary supplementation with dried oregano improved rabbit performance, while Pogany-Simonova et al. [99] reported that oregano and sage extracts improved rabbit health and carcass amino acid composition. Other researchers [97,98] found that oregano essential oil had no effect on performance parameters of rabbits and significantly increased the antioxidative capacity of raw and thermally treated carcasses during refrigerated storage. Additionally, dietary oregano essential oil was effective in inhibiting microbial growth on rabbit carcasses during refrigerated storage [98]. These carcasses also exhibited noticeably less slime and off-odors than the controls. It is possible that oregano essential oil components entered the circulatory system, were distributed and retained in tissues and thus are responsible for the exhibited antioxidant and antimicrobial activities. The bioavailability of any of these components cannot be directly demonstrated, since an analytical method capable of identifying and quantifying them at trace levels in tissues has not yet been developed [98]. 


\subsection{The Use of Aromatic Plants in Ruminant Nutrition}

Evidence for in vivo antimicrobial activity of aromatic plant essential oils has not yet been confirmed in ruminants, although oils have been used to manipulate ruminal metabolism in order to improve feed efficiency and animal productivity [11,54]. Nevertheless, results from in vitro batch culture studies provide evidence that essential oils or their components have the potential to improve nitrogen and/or energy utilization in ruminants by altering microbial populations [44]. These responses are only observed with high doses of essential oils, which also can inhibit the process of ruminal fermentation causing a decline in total volatile fatty acid production, although rumen microbial populations adapt after long term exposure to these substances [44,54]. Also, the fact that some aromatic plants derived substances show a strong bactericidal activity against pathogenic bacteria such as Escherichia coli and Salmonella spp. [110], has prompted some researchers to examine their potential to reduce ruminal methanogenesis [44,101,102], limiting the release of this important greenhouse gas into the atmosphere.

In vivo research using novel aromatic plants in rumen nutrition has the potential to benefit animal production and health, as well as the environment.

\section{Conclusions}

Aromatic plants, their extracts and essential oils contain a variety of functional bioactive compounds, which have possible applications in the food, feed, pharmaceutical and cosmetic industries. However, aromatic plants and their extracts should be standardized and properly controlled in their extraction and composition, in order for the study of these plants to yield meaningful data. In vitro studies using standardized extracts should be completed prior to in vivo experimental research, to confirm the efficacy of the extracts. In this way, viable alternative methods for enhancing performance or improving shelf-life of the animal products may be developed, satisfying the consumer's demands for natural, safe and high quality foods.

\section{References}

1. Sacchetti, G.; Maietti, S.; Muzzoli, M.; Scaglianti, M.; Manfredini, S.; Radice, M.; Bruni, R. Comparative evaluation of 11 essential oils of different origin as functional antioxidants, antiradicals and antimicrobials in foods. Food Chem. 2005, 91, 621-632.

2. Giannenas, I. How to use plant extracts and phytogenics in animal diets. In World Nutrition Forum, the Future of Animal Nutrition; Binder, E.M., Schatzmayr, G., Eds.; Nottingham University Press: Nottingham, UK, 2008; pp. 111-129.

3. Chang, J. Medicinal herbs: Drugs or dietary supplements? Biochem. Pharmacol. 2000, 59, 211-219.

4. Li, T.S.C. The range of medicinal herbs and spices. In Handbook of Herbs and Spices; Peter, K.V., Ed.; Woodhead Publishing Limited: Cambridge, UK, 2006; Volume 3, pp. 113-125.

5. Piccaglia, R.; Marotti, M.; Giovanelli, E.; Deans, S.G.; Eaglesham, E. Antibacterial and antioxidant properties of mediterranean aromatic plants. Ind. Crops Prod. 1993, 2, 47-50. 
6. Collin, H. Herbs, spices and cardiovascular disease. In Handbook of Herbs and Spices; Peter, K.V., Ed.; Woodhead Publishing Limited: Cambridge, UK, 2006; Volume 3, pp. 126-137.

7. Gurib-Fakim, A. Medicinal plants: Traditions of yesterday and drugs of tomorrow. Mol. Aspects Med. 2006, 27, 1-93.

8. Windisch, W.; Rohrer, E.; Schedle, K. Phytogenic feed additives to young piglets and poultry: Mechanisms and application. In Phytogenics in Animal Nutrition: Natural Concepts to Optimize Gut Health and Performance; Steiner, T., Ed.; Nottingham University Press: Nottingham, UK, 2009; pp. 19-38.

9. Brenes, A.; Roura, E. Essential oils in poultry nutrition: Main effects and modes of action. Anim. Feed Sci. Technol. 2010, 158, 1-14.

10. Varel, V.H. Livestock manure odor abatement with plant-derived oils and nitrogen conservation with urease inhibitors: A review. J. Anim. Sci. 2002, 80, E1-E7.

11. Greathead, H. Plants and plant extracts for improving animal productivity. Proc. Nutr. Soc. 2003, 62, 279-290.

12. Barton, M.D. The down-side of antibiotic use in pig production: The effect of antibiotic resistance of enteric bacteria. In Manipulating Pig Production; Carnwell, P.D., Ed.; Australasian Pig Science Association: Victoria, Australia, 1999; Volume 7.

13. Bampidis, V.A.; Christodoulou, V.; Christaki, E.; Florou-Paneri, P.; Spais, A.B. Effect of dietary garlic bulb and garlic husk supplementation on performance and carcass characteristics of growing lambs. Anim. Feed Sci. Technol. 2005, 121, 273-283.

14. Botsoglou, N.A.; Taitzoglou, I.A.; Botsoglou, E.; Zervos, I.; Kokoli, A.; Christaki, E.; Nikolaidis, E. Effect of long-term dietary administration of oregano and rosemary on the antioxidant status of rat serum, liver, kidney and heart after carbon tetrachloride-induced oxidative stress. J. Sci. Food Agric. 2009, 89, 1397-1406.

15. Ocak, N.; Erener, G.; Burak, A.F.; Sungu, M.; Altop, A.; Ozmen, A. Performance of broilers fed diets supplemented with dry peppermint (Mentha piperita L.) or thyme (Thymus vulgaris L.) leaves as growth promoter source. Czech J. Anim. Sci. 2008, 53, 169-175.

16. Kadri, A.; Zarai, Z.; Chobba, I.B.; Bekir, A.; Gharsallah, N.; Damak, M.; Gdoura, R. Chemical constituents and antioxidant properties of Rosmarinus officinalis L. essential oil cultivated from South-Western Tunisia. J. Med. Plants Res. 2011, 5, 5999-6004.

17. Perumalla, A.V.S.; Hettiarachchy, N.S. Green tea and grape seed extracts-Potential applications in food safety and quality. Food Res. Int. 2011, 44, 827-839.

18. Negi, P.S. Plant extracts for the control of bacterial growth: Efficacy, stability and safety issues for food application. Int. J. Food Microbiol. 2012, 156, 7-17.

19. Cowan, M.M. Plant products as antimicrobial agents. Clin. Microbiol. Rev. 1999, 12, 564-582.

20. Tiwari, S. Plants: A rich source of herbal medicine. J. Nat. Prod. 2008, 1, 27-35.

21. Madsen, H.L.; Bertelsen, G. Spices as antioxidants. Trends Food Sci. Technol. 1995, 6, 271-277.

22. Duthie, G.G.; Brown, K.M. Functional foods. In Reducing the Risk of Cardiovascular Disease; Goldberg, I., Ed.; Chapman \& Hall: London, UK, 1994; pp. 19-38.

23. Milner, J.A. Functional foods. In Reducing the Risk of Cancer; Goldberg, I., Ed.; Chapman \& Hall: London, UK, 1994; pp. 39-70. 
24. Couladis, M.; Tzakou, O.; Verykokidou, E.; Harvala, C. Screening of some greek aromatic plants for antioxidant activity. Phytother. Res. 2003, 17, 194-195.

25. Duke, J. Handbook of Medicinal Spices; CRC Press: Boca Raton, FL, USA, 2002.

26. Sherman, P.W.; Flaxman, S.M. Protecting ourselves from food. Am. Sci. 2001, 89, 142-151.

27. Elgayyar, M.; Draughon, F.A.; Golden, D.A.; Mount, J.R. Antimicrobial activity of essential oils from plants against selected pathogenic and saprophytic microorganisms. J. Food Protect. 2001, 64, 1019-1024.

28. Bernath, J. Aromatic plants. In Cultivated Plants, Primarily as Food Sources; Fuleky, G., Ed.; EOLSS: Paris, France, 2009; Volume 2, pp. 329-352.

29. Bakkali, F.; Averbeck, S.; Averbeck, D.; Idaomar, M. Biological effects of essential oils-A review. Food Chem. Toxicol. 2008, 46, 446-475.

30. Lubbe, A.; Verpoorte, R. Cultivation of medicinal and aromatic plants for specialty industrial materials. Ind. Crops Prod. 2011, 34, 785-801.

31. Basile, A.; Senatore, F.; Gargano, R.; Sorbo, S.; Del Pezzo, M.; Lavitola, A.; Ritieni, A.; Bruno, M.; Spatuzzi, D.; Rigano, D.; et al. Antibacterial and antioxidant activities in Sideritis italica (miller) Greuter et Burdet essential oils. J. Ethnopharmacol. 2006, 107, 240-248.

32. Duschatzky, C.B.; Possetto, M.L.; Talarico, L.B.; Garcia, C.C.; Michis, F.; Almeida, N.V.; Lampasona, M.P.D.; Schuff, C.; Damonte, E.B. Evaluation of chemical and antiviral properties of essential oils from south american plants. Antivir. Chem. Chemother. 2005, 16, 247-251.

33. Hammer, K.A.; Carson, C.F.; Riley, T.V. In vitro activity of Melaleuca alternifolia (tea tree) oil against dermatophytes and other filamentous fungi. J. Antimicrob. Chemother. 2002, 50, 195-199.

34. Moon, T.; Wilkinson, J.M.; Cavanagh, H.M. Antiparasitic activity of two Lavandula essential oils against Giardia duodenalis, Trichomonas vaginalis and Hexamita inflata. Parasitol. Res. 2006, 99, 722-728.

35. Yang, P.; Ma, Y. Repellent effect of plant essential oils against Aedes albopictus. J. Vector Ecol. 2005, 30, 231-234.

36. Srinivasan, K. Spices as influencers of body metabolism: An overview of three decades of research. Food Res. Int. 2004, 38, 77-86.

37. Botsoglou, N.A.; Christaki, E.; Florou-Paneri, P.; Giannenas, I.; Papageorgiou, G.; Spais, A.B. The effect of a mixture of herbal essential oils or a-tocopheryl acetate on performance parameters and oxidation of body lipid in broilers. S. Afr. J. Anim. Sci. 2004, 34, 52-61.

38. Platel, K.; Srinivasan, K. Digestive stimulant action of spices: A myth or reality? Indian J. Med. Res. 2004, 119, 167-179.

39. Ultee, A.; Smid, E.J. Influence of carvacrol on growth and toxin production by Bacillus cereus. Int. J. Food Microbiol. 2001, 64, 373-378.

40. Van de Braak, S.A.A.J.; Leijten, G.C.J.J. Essential Oils and Oleoresins: A Survey in The Netherlands and Other Major Markets in the European Union; CBI, Centre for the Promotion of Imports from Developing Countries: Rotterdam, Netherlands, 1999.

41. Svoboda, K.A.; Hampson, J.B. Bioactivity of essential oils of selected temperate aromatic plants: Antibacterial, antioxidant, antiinflamatory and other related pharmacological activities. In Procceedings of NAHA, St. Louis, MO, USA, 25-28 September 1999; pp. 105-127. 
42. Giannenas, I.; Kyriazakis, I. Phytobased production for the control of intestinal diseases in chicken in the post antibiotic era. In Phytogenics in Animals Nutrition. Natural Concepts to Optimize Gut Health and Performance; Steiner, T., Ed.; Nottingham University Press: Nottingham, UK, 2009; pp. 61-85.

43. Solorzano-Santos, F.; Miranda-Novales, M.G. Essential oils from aromatic herbs as antimicrobial agents. Curr. Opin. Biotechnol. 2012, 23, 136-141.

44. Benchaar, C.; Calsamiglia, S.; Chaves, A.V.; Fraser, G.R.; Colombatto, D.; McAllister, T.A.; Beauchemin, K.A. A review of plant-derived essential oils in ruminant nutrition and production. Anim. Feed Sci. Technol. 2008, 145, 209-228.

45. Lorenzi, V.; Muselli, A.; Bernardini, A.F.; Berti, L.; Pagès, J.-M.; Amaral, L.; Bolla, J.-M. Geraniol restores antibiotic activities against multidrug-resistant isolates from gram-negative species. Antimicrob. Agents Chemother. 2009, 53, 2209-2211.

46. Devi, K.P.; Nisha, S.A.; Sakthivel, R.; Pandian, S.K. Eugenol (an essential oil of clove) acts as an antibacterial agent against Salmonella typhi by disrupting the cell membrane. J. Ethnopharmacol. 2010, 130, 107-115.

47. Farag, R.S.; Daw, Z.; Hewed, F.; El-Baroty, G. Antimicrobial activity of some Egyptian spice essential oils. J. Food Prot. 1989, 52, 665-667.

48. Bowles, B.; Miller, A. Antibotulinal properties of selected aromatic and aliphatic aldehydes. J. Food Prot. 1993, 56, 788-794.

49. Panghal, M.; Kaushal, V.; Yadav, J.P. In vitro antimicrobial activity of ten medicinal plants against clinical isolates of oral cancer. Ann. Clin. Microbiol. Antimicrob. 2011, 10, 20-21.

50. Sharafi, S.M.; Rasooli, I.; Owlia, P.; Taghizadeh, M.; Astaneh, S.D. Protective effects of bioactive phytochemicals from Mentha piperita with multiple health potentials. Pharmacogn. Mag. 2010, 6, 147-153.

51. Van Vuuren, S.F.; du Toit, L.C.; Parry, A.; Choonara, Y.E. Encapsulation of essential oils within a polymeric liposomal formulation for enhancement of antimicrobial efficacy. Nat. Prod. Commun. 2010, 5, 1401-1408.

52. Dorman, H.J.D.; Deans, S.G. Antimicrobial agents from plants: Antibacterial activity of plant volatile oils. J. Appl. Microbiol. 2000, 88, 308-316.

53. Lambert, R.J.W.; Skandamis, P.N.; Coote, P.J.; Nychas, G.J.E. A study of the minimum inhibitory concentration and mode of action of oregano essential oil, thymol and carvacrol. J. Appl. Microbiol. 2001, 91, 453-462.

54. Benchaar, C.; Hristov, A.N.; Greathead, H. Essential oils as feed additives in ruminant nutrition. In Phytogenics in Animal Nutrition; Steiner, T., Ed.; Nuttingham University Press: Nottingham, UK, 2009; pp. 111-146.

55. Hellander, M.; Alakomi, H.; Latva-Kala, K.; Mattila-Sandholm, T.; Pol, I.; Smid, E.J.; Gorris, L.G.M.; Wright, A.V. Characterization of the action of selected essential oil components on gram-negative bacteria. J. Agric. Food Chem. 1998, 46, 3590-3595.

56. Juliano, C.; Mattana, A.; Usai, M. Composition and in vitro antimicrobial activity of the essential oil of thymus herba-barona loisel growing wild in sardinia. J. Essent. Oil Res. 2000, 12, 516-522. 
57. Blay, G.; Michel, C.; Blottiere, H.; Cherbut, C. Prolonged intake of fructo-oligosaccharides induces a short term elevation of lactic acid-producing bacteria and a persistent increase in cecal butyrate in rats. J. Nutr. 1999, 129, 2231-2235.

58. Franz, C.; Baser, K.H.C.; Windisch, W. Essential oils and aromatic plants in animal feeding-An European perspective: A review. Flavour Fragr. J. 2010, 25, 327-340.

59. Kahkonen, M.P.; Hopia, A.I.; Vuorela, H.J.; Rauha, J.-P.; Pihlaja, K.; Kujala, T.S.; Heinonen, M. Antioxidant activity of plant extracts containing phenolic compounds. J. Agric. Food Chem. 1999, 47, 3954-3962.

60. Sakakibara, H.; Hona, Y.; Nagawaga, S.; Ashida, H.; Kanazawa, K. Simultaneous determination of all polyphenols in vegetables, fruits and teas. J. Agric. Food Chem. 2003, 51, 571-581.

61. Rice-Evans, C.A.; Miller, N.J.; Bolwell, P.G.; Bramley, P.M.; Pridham, J.B. The relative antioxidant activities of plant derived polyphenolic flavonoids. Free Radic. Res. 1995, 22, 375-383.

62. Chun, S.-S.; Vattem, D.A.; Lin, Y.-T.; Shetty, K. Phenolic antioxidants from clonal oregano (Origanum vulgare) with antimicrobial activity against Helicobacter pylori. Process Biochem. 2005, 40, 809-816.

63. Zheng, W.; Wang, S.Y. Antioxidant activity and phenolic compounds in selected herbs. J. Agric. Food Chem. 2001, 49, 5165-5170.

64. Miron, T.L.; Gazi, I.; Plaza del Moral, M. Romanian aromatic plants as source of antioxidants. Innov. Romanian Food Biotechnol. 2010, 6, 18-24.

65. Shetty, K. Biotechnology to harness the benefits of dietry phenolics: Focus on lamiaceae. Asia Pac. J. Clin. Nutr. 1997, 6, 162-171.

66. Proestos, C.; Boziaris, I.S.; Nychas, G.J.E.; Komaitis, M. Analysis of flavonoids and phenolic acids in greek aromatic plants: Investigation of their antioxidant capacity and antimicrobial activity. Food Chem. 2006, 95, 664-671.

67. Miguel, M.G. Antioxidant activity of medicinal and aromatic plants. A review. Flavour Fragr. J. 2010, 25, 291-312.

68. Frankel, E.N. In search for better methods to evaluate natural antioxidants and oxidative stability in food lipids. Trends Food Sci. Technol. 1993, 4, 220-225.

69. Hussain, A.I.; Anwar, F.; Sherazi, S.T.H.; Przybylski, R. Chemical composition, an antioxidant and antimicrobial activity of basil (Ocimum basilicum) essential oils depends on seasonal variations. Food Chem. 2008, 108, 986-995.

70. Montoro, P.; Braca, A.; Pizza, C.; de Tommasi, N. Structure-antioxidant activity relationships of flavonoids isolated from different plant species. Food Chem. 2005, 92, 349-355.

71. Heim, K.E.; Tagliaferro, A.R.; Bobilya, D.J. Flavonoid antioxidants: Chemistry, metabolism and structure-activity relationships. J. Nutr. Biochem. 2002, 3, 572-584.

72. Botsoglou, N.A.; Florou-Paneri, P.; Christaki, E.; Fletouris, D.J.; Spais, A.B. Effect of dietary oregano essential oil on performance of chickens and iron-induced lipid oxidation of breast, thigh and abdominal fat tissues. Br. Poult. Sci. 2002, 43, 223-230.

73. Basset, R. Oregano's positive impact on poultry nutrition. World Poult. 2000, 16, 31-34. 
74. Giannenas, I.; Florou-Paneri, P.; Papazahariadou, M.; Christaki, E.; Botsoglou, N.A.; Spais, A.B. Dietary oregano essential oil supplementation on performance of broilers challenged with eimeria tenella. Arch. Anim. Nutr. 2003, 57, 99-106.

75. Botsoglou, N.A.; Christaki, E.; Fletouris, D.J.; Florou-Paneri, P.; Spais, A.B. The effect of dietary oregano essential oil on lipid oxidation in raw and cooked chicken during refrigerated storage. Meat Sci. 2002, 62, 259-265.

76. Botsoglou, N.A.; Fletouris, D.J.; Florou-Paneri, P.; Christaki, E.; Spais, A.B. Inhibition of lipid oxidation in long-term frozen stored chicken meat by dietary oregano essential oil and $\alpha$-tocopheryl acetate supplementation. Food Res. Int. 2003, 36, 207-213.

77. Giannenas, I.; Florou-Paneri, P.; Botsoglou, N.A.; Christaki, E.; Spais, A.B. Effect of feed supplementation with dehydrated oregano plants on the performance of broiler chickens and the oxidative stability of the produced meat. J. Animal Feed Sci. 2005, 14, 521-535.

78. Giannenas, I.; Florou-Paneri, P.; Papazahariadou, M.; Botsoglou, N.A.; Christaki, E.; Spais, A.B. Effect of diet supplementation with ground oregano on performance of broiler chickens challenged with Eimeria tenella. Archiv fur Geflugelkunde 2004, 68, 247-252.

79. Ciftci, M.; Guler, T.; Dalkilic, B.; Ertas, O.N. The effect of anise oil (Pimpinella anisum) on broiler performance. Int. J. Poult. Sci. 2005, 4, 851-855.

80. Soltan, M.A.; Shewita, R.S.; El-Katcha, M.I. Effects of diary anise seeds supplementation on growth performance, immune response, carcass traits and some bool parameters of broiler chickens. Int. J. Poult. Sci. 2008, 7, 1078-1088.

81. Chen, A.; Xu, J.; Yang, C.; Hong, Q. Effect of cinnamon extracts on growth performances and excreta urease activitu and nitrogen loss in broilers. In Livestock Environment VIII; Curran Associates Inc.: Iguassu Falls, Brazil, 2008; Volume 1.

82. Al-Kassie, G.A.M. Influence of two plant extracts derived from thyne and cinnamon on broiler performance. Pakistan Vet. J. 2009, 29, 169-173.

83. Lopez-Bote, C.J.; Gray, J.I.; Gomaa, E.A.; Flegal, C.J. Effect of dietary administration of oil extracts from rosemary and sage on lipid oxidation in broiler meat. Br. Poult. Sci. 1998, 39, 235-240.

84. Allen, P.C.; Lydon, J.; Danforth, H.D. Effects of components of Artemisia annua on coccidia infections in chickens. Poult. Sci. 1997, 76, 1156-1163.

85. Youn, H.J.; Noh, J.W. Screening of the anticoccidial effects of herb extracts against Eimeria tenella. Vet. Parasitol. 2001, 96, 257-263.

86. Florou-Paneri, P.; Christaki, E.; Giannenas, I.; Papazahariadou, M.; Botsoglou, N.A.; Spais, A.B. Effect of dietary olympus tea (Sideritis scardica) supplementation on performance of chickens challenged with Eimeria tenella. J. Anim. Feed Sci. 2004, 13, 301-311.

87. Evans, J.W.; Plunkett, M.; Banfield, M. Effect of an essential oil blend on coccidiosis in broiler chicks. Poult. Sci. 2001, 80, 258.

88. Christaki, E.; Florou-Paneri, P.; Giannenas, I.; Papazahariadou, M.; Botsoglou, N.A.; Spais, A.B. Effect of a mixture of herbal extracts on broiler chickens infected with Eimeria tenella. Anim. Res. 2004, 53, 137-144.

89. Arczewska-Wlosek, A.; Swiatkiewicz, S. The effect of a dietary herbal extract blend on the performance of broilers challenged with eimeria oocysts. J. Anim. Feed Sci. 2012, 21, 133-142. 
90. Bozkurt, M.; Kucukyllmaz, K.; Pamukcu, M.; Cabuk, M.; Alcicek, A.; Catli, A.U. Long-term effects of dietary supplementation with an essential oil mixture on the growth and laying performance of two layer strains. Italian J. Anim. Sci. 2012, 11, 23-28.

91. Botsoglou, N.A.; Florou-Paneri, P.; Botsoglou, E.; Dotas, V.; Giannenas, I.; Koidis, A.; Mitrakos, P. The effect of feeding rosemary, oregano, saffron and $\alpha$-tocopheryl acetate on hen performance and oxidative stability of eggs. S. Afr. J. Anim. Sci. 2005, 35, 143-151.

92. Papageorgiou, G.; Botsoglou, N.; Govaris, A.; Giannenas, I.; Iliadis, S.; Botsoglou, E. Effect of dietary oregano oil and alpha-tocopheryl acetate supplementation on iron-induced lipid oxidation of turkey breast, thigh, liver and heart tissues. J. Anim. Physiol. Anim. Nutr. 2003, 87, 324-335.

93. Bampidis, V.A.; Christodoulou, V.; Florou-Paneri, P.; Christaki, E.; Chatzopoulou, P.S.; Tsiligianni, T.; Spais, A.B. Effect of dietary dried oregano leaves on growth performance, carcase characteristics, and serum cholesterol of female early-maturing turkeys. Br. Poult. Sci. 2005, 46, 595-601.

94. Suriya, R.; Zulkifli, I.; Alimon, A.R. The effect of dietary inclusion of herbs as growth promoter in broiler chickens. J. Anim. Vet. Advan. 2012, 11, 346-350.

95. Christaki, E.; Bonos, E.; Giannenas, I.; Florou-Paneri, P. Evaluation of oregano and $\alpha$-tocopheryl acetate on laying Japanese quail diets. J. Basic Appl. Sci. 2012, 8, 238-242.

96. Christaki, E.; Bonos, E.; Florou-Paneri, P. Use of anise seeds and/or $\alpha$-tocopheryl acetate in laying Japanese quail diets. S. Afr. J. Anim. Sci. 2011, 41, 126-133.

97. Botsoglou, N.A.; Florou-Paneri, P.; Christaki, E.; Giannenas, I.; Spais, A.B. Performance of rabbits and oxidative stability of muscle tissues as affected by dietary supplementation with oregano essential oil. Arch. Anim. Nutr. 2004, 58, 209-218.

98. Soultos, N.; Tzikas, Z.; Christaki, E.; Papageorgiou, K.; Steris, V. The effect of dietary oregano essential oil on microbial growth of rabbit carcasses during refrigerated storage. Meat Sci. 2009, $81,474-478$.

99. Pogany Simonova, M.; Chrastinova, L.; Mojto, J.; Laukova, A.; Szaboova, R.; Rafay, J. Quality of rabbit meat and phyto-additives. Czech J. Food Sci. 2010, 28, 161-167.

100. Ayala, L.; Silvana, N.; Zocarrato, I.; Gomez, S. Use of vulgar oregano (Origanum vulgare) as phytobiotic in fatting rabbits. Cuban J. Agric. Sci. 2011, 45, 159-161.

101. McIntosh, F.M.; Williams, P.; Losa, R.; Wallace, R.J.; Beever, D.A.; Newbold, C.J. Effects of essential oils on ruminal microorganisms and their protein metabolish. Appl. Environ. Microbiol. 2003, 69, 5011-5014.

102. Mohammed, N.; Ajisaka, N.; Lila, Z.A.; Mikuni, K.; Hara, K.; Kanda, S.; Itabashi, H. Effect of Japanese horseradish oil on methane production and ruminal fermentation in vitro and in steers. J. Anim. Sci. 2004, 82, 1839-1846.

103. Kokkini, S.; Vokou, D. Carvarol-rich plants in greece. Flavour Fragr. J. 1989, 4, 1-7.

104. Vokou, D.; Kokkini, S. Geographic variation of Greek oregano (Origanum vulgare ssp. Hirtum) essential oils. Biochem. Syst. Ecol. 1993, 21, 287-295.

105. Boskabady, M.H.; Ramazani-Assari, M. Relaxant effect of Pimpinella anisum on isolated guinea pig tracheal chains and its possible mechanism(s). J. Ethnopharmacol. 2001, 74, 83-88.

106. Ankri, S.; Mirelman, D. Antimicrobial properties of allicin from garlic. Microbes Infect. 1999, 1, $125-129$. 
107. Danforth, H.D. Use of live oocyst vaccines in the control of avian coccidiosis: Experimental studies and field trials. Int. J. Parasitol. 1998, 28, 1099-1109.

108. Abbas, R.Z.; Colwell, D.D.; Gilleard, J. Botanicals: An alternative approach for the control of avian coccidiosis. World's Poult. Sci. J. 2012, 68, 203-215.

109. The European Parliament; The Council of The European Union. Regulation (EC) No 1831/2003 of the European Parliament and of the Council of 22 September 2003 on additives for use in animal nutrition. Off. J. Eur. Union 2003, L268, 29-43.

110. Oussalah, M.; Caillet, S.; Saucier, L.; Lacroix, M. Inhibitory effects of selected essential oils on the growth of four pathogenic bacteria: E. coli O157:H7, Salmonella typhimurium, Staphylococcus aureus and Listeria monocytogenes. Food Control 2007, 18, 414-420.

(C) 2012 by the authors; licensee MDPI, Basel, Switzerland. This article is an open access article distributed under the terms and conditions of the Creative Commons Attribution license (http://creativecommons.org/licenses/by/3.0/). 